Check for updates

Cite this: RSC Adv., 2019, 9, 5756

Received 4th January 2019

Accepted 12th February 2019

DOI: $10.1039 / \mathrm{c} 9 \mathrm{ra00079h}$

rsc.li/rsc-advances

\section{Reusable bentonite clay: modelling and optimization of hazardous lead and $p$-nitrophenol adsorption using a response surface methodology approach}

\begin{abstract}
Mohamed Zbair, (DD ${ }^{* a}$ Zakaria Anfar (DD ${ }^{b}$ and Hassan Ait Ahsaine (DD ${ }^{b}$
In this work, bentonite clay (BC) calcined at $500^{\circ} \mathrm{C}$ was used as an adsorbent (BC-500) for the adsorption of $\mathrm{Pb}^{2+}$ and $p$-nitrophenol. The ability of $\mathrm{BC}-500$ for the removal of $\mathrm{Pb}^{2+}$ and $p$-nitrophenol has been investigated. The adsorption studies tailored well the pseudo-first-order and the Langmuir model for $\mathrm{Pb}^{2+}$ and $p$-nitrophenol both. In addition, the optimal removal of $\mathrm{Pb}^{2+}$ and $p$-nitrophenol was found at $\mathrm{pH} 5$ for $\mathrm{Pb}^{2+}$ and $\mathrm{pH} 6$ for $\mathrm{p}$-nitrophenol. However, the change of temperature $\left(20-60{ }^{\circ} \mathrm{C}\right.$ ) was found to have a negative effect on the adsorption process on BC-500. Based on the Dubinin-Radushkevich model the adsorption occurs via a physical process. Accordingly, the adsorption mechanism was proposed using $\mathrm{N}_{2}$-physisorption analysis before and after adsorption of $\mathrm{Pb}^{2+}$ and $p$-nitrophenol. The reusability of $\mathrm{BC}-500$ was examined and the outcomes recommended that BC-500 had good potential as an economic and proficient adsorbent for $\mathrm{Pb}^{2+}$ or $p$-nitrophenol from contaminated water. Finally, the experimental $\mathrm{Pb}^{2+}$ and $p$-nitrophenol removal efficiency were found to be $90.93 \pm 2.15 \%$ and 98.06 $\pm 1.87 \%$ while the predicted value by model equals $91.28 \pm 1.68$ and $97.24 \pm 2.54$, respectively, showing that the predicted model values are in good agreement with the experimental value.
\end{abstract}

\section{Introduction}

At present, pollution caused by organic and inorganic compounds is a major problem for the world and is likely to cause health hazards, harm to ecology, damage to structures or amenities, and interference with the legitimate use of water. ${ }^{1}$ Industries such as papermaking, electroplating, metal finishing, textiles, storage batteries, lead smelting, mining, plating, ceramics, leather, food, rubber, cosmetics, and plastics use different chemical compounds, which makes it possible to produce toxic effluents containing organic and inorganic contaminants. ${ }^{2}$ Lead $(\mathrm{Pb})$ is one of the most toxic elements, even at low concentrations, because of its presence in automobile fuel and the subsequent emission into the atmosphere in the exhaust gases. $^{3} \mathrm{~Pb}$ (II) metals affect the central nervous system, kidneys, liver, and gastrointestinal system, and may directly or indirectly cause diseases such as anemia, encephalopathy, hepatitis, and the nephrotic syndrome. ${ }^{4} p$-Nitrophenol is another toxic pollutant (found particularly in the effluents from pesticides, pharmaceuticals, petrochemicals, and other industries) with an impact on many organisms that live in aquatic ecosystems. The

${ }^{a}$ Laboratory of Catalysis and Corrosion of Materials, Chouaïb Doukkali University, Faculty of Sciences El Jadida, BP. 20, El Jadida 24000, Morocco. E-mail: zbair. mohamed@gmail.com

${ }^{b}$ Materials and Environment Laboratory, Ibn Zohr University, Faculty of Sciences, Agadir, Morocco presence of $p$-nitrophenol and its analogues in the environment has become a great concern in recent years because of their increased discharge, toxic nature and adverse effects on the receiving water bodies. ${ }^{5}$ Moreover, $p$-nitrophenol is responsible to cause degeneration in human proteins, tissue erosion, paralysis of the central nervous system, and damage to the liver, kidney and pancreas. ${ }^{6}$ As a priority toxin (US Environmental Protection Agency) because of its potential harm on aquatic life, plants and human beings even at low concentrations. $p$-Nitrophenol is a common constituent of contaminated soil, ground water or leachate. ${ }^{7,8}$ Hence, $p$-nitrophenol may cause severe environmental and public health problems, and it is mandatory to be treated before being discharged into the environment.

The wide usage of $\mathrm{Pb}(\mathrm{II})$ and $p$-nitrophenol in various industries have triggered the necessities of developing an efficient method to remove these pollutants from wastewaters. ${ }^{9}$ The most common methods for removal of these pollutants from industrial effluents include chemical precipitation, oxidation, and ion exchanges and adsorption etc., ${ }^{7,8,10}$ Adsorption process belongs to this category and it is found to be very effective and is applied in the liquid phase.,11-20 Many adsorbents have been tested on the adsorption of $\mathrm{Pb}^{2+}$ and $p$-nitrophenol. For instance, Tran et al. ${ }^{11}$ have been reported $4.112 \mathrm{mmol} \mathrm{g}^{-1}$ of $\mathrm{Pb}^{2+}$ adsorption capacity using phenylalanine-Mg/AL(LDH). Yuanqing Huang et $a .^{21}$ have utilized a nitrilotriacetic acid anhydride modified ligno-cellulosic 

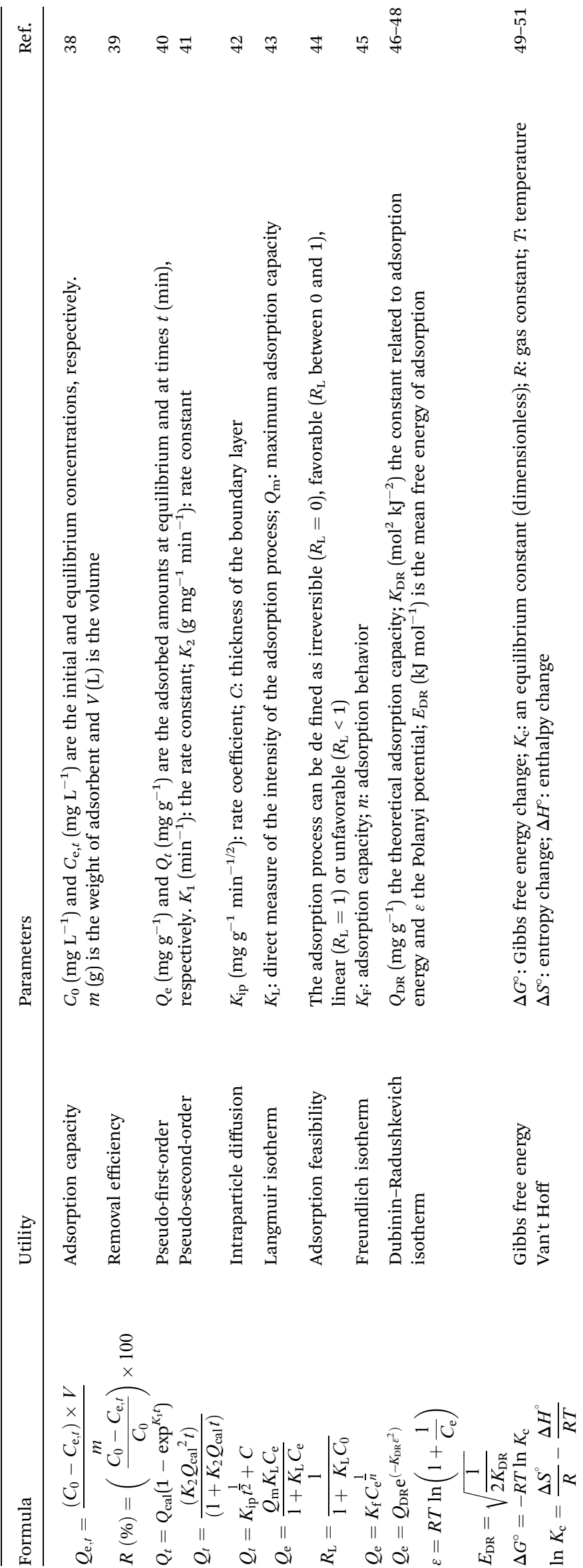
material (NTAA-LCM) toward $\mathrm{Pb}^{2+}$ removal and indicated an adsorption capacity of $303.5 \mathrm{mg} \mathrm{g}^{-1}$ at $298 \mathrm{~K}$. Also, $\mathrm{Pb}^{2+}$ was biosorbed using waste biomass $\left(160 \mathrm{mg} \mathrm{g}^{-1}\right.$ at $\left.25{ }^{\circ} \mathrm{C}\right) .{ }^{22}$ For $p$ nitrophenol removal, Q. Zhang et al. ${ }^{23}$ have been found an adsorption capacity of $102 \mathrm{mg} \mathrm{g}^{-1}$ by ZnAl-layered double hydroxides. B. Liu et al. ${ }^{24}$ reached a capacity of $11 \mathrm{mg} \mathrm{g}^{-1}$ by coal fly ash. Furthermore, Muthanna J. Ahmed et al..$^{25}$ have been utilized microporous activated carbon with an adsorption capacity of $185 \mathrm{mg} \mathrm{g}^{-1}$.

In recent years, clays are alternative solutions for acting as activated carbon. Clays have been used for thousands of years and continue to be among the leading industrial material because they are natural, earthy and fine-grained material. ${ }^{26}$ For a long time, clays have been also used for adsorption of various organic, inorganic substances due to its low cost and high removal efficiency (high surface area and exchange capacities). ${ }^{10,27-31}$ However, on our knowledge there is lack of information on the adsorption of $\mathrm{Pb}$ (II) and $p$-nitrophenol especially on bentonite clay and the effect of some variables on its adsorption capacity, optimization using response surface methodology and regeneration. The Response Surface Methodology (RSM) is a collection of mathematical and statistical techniques useful for the modeling and analysis of problems in which response of interest is affected by several variables (Kumar et al., 2017). Several published paper has been reported the utilization of RSM for the optimization and verification of scientific researches and industrial studies. ${ }^{32-34}$

In this research, bentonite clay (BC) from the region of Safi (Morocco) has been used as an adsorbent to remove $\mathrm{Pb}^{2+}$ and $p$ nitrophenol from aqueous solution. Adsorption experiments have been performed to look for equilibrium as well as adsorption kinetics. The experimental data were compared with by others studies and adsorption mechanism was proposed. RSM approach also was applied to determine the optimum removal efficiency and also to explain the relations between $\mathrm{Pb}^{2+}$ and $p$-nitrophenol removal and the pertinent parameters.

\section{Experimental}

\subsection{Adsorbent's preparation}

The adsorbent used in this study is the bentonite clay (BC) from the region of Safi (Morocco). The BC was primarily washed

Table 2 Experimental levels for $p$-nitrophenol adsorption

\begin{tabular}{lllrrrrr}
\hline Variable & Factor & Unit & $-1.68(\alpha)$ & -1 & 0 & 1 & $+1.68(\alpha)$ \\
\hline$X_{1}$ & $\mathrm{pH}$ & - & 2.63 & 4 & 6 & 8 & 9.36 \\
$X_{2}$ & Temperature & ${ }^{\circ} \mathrm{C}$ & 11.59 & 15 & 20 & 25 & 28.40 \\
$X_{3}$ & Concentration & $\mathrm{mg} \mathrm{L}^{-1}$ & 39.90 & 44 & 50 & 56 & 60.09
\end{tabular}

Table 3 Experimental levels for lead adsorption

\begin{tabular}{lllrrrrr}
\hline Variable & Factor & Unit & $-1.68(\alpha)$ & -1 & 0 & 1 & $+1.68(\alpha)$ \\
\hline$X_{1}$ & $\mathrm{pH}$ & - & 1.63 & 3 & 5 & 8 & 8.36 \\
$X_{2}$ & Temperature & ${ }^{\circ} \mathrm{C}$ & 11.59 & 15 & 20 & 25 & 28.40 \\
$X_{3}$ & Concentration & $\mathrm{mg} \mathrm{L}^{-1}$ & 39.90 & 44 & 50 & 56 & 60.09
\end{tabular}

several times and then milled and sieved, acquiring the average diameter of $10 \mu \mathrm{m}$. The clay was subsequently calcined over $500{ }^{\circ} \mathrm{C}$ in a muffle for a period of $6 \mathrm{~h}$. The calcination process is used in order to increase the adsorbent's stability. The obtained material was labeled: BC-500.

\subsection{Characterization of adsorbent}

BC-500 was analyzed using the X-ray diffraction (diffractometer Bruker D8 Advanced). Copper $\mathrm{K} \alpha$ radiation $(\lambda=1.5406 \mathrm{~nm})$ produced at $50 \mathrm{kV}$ and $20 \mathrm{~mA}$. Infrared Spectra of BC-500 was recorded using Fourier Transform Spectrometer (Shimadzu FTIR-8400S) with a resolution of $4 \mathrm{~cm}^{-1}$ and 20 scans (400 to $4000 \mathrm{~cm}^{-1}$ ). The surface area of BC-500 was determined using Micromeritics ASAP 2010. Scanning Electron Microscopy analysis was done using (Hitachi S2500, Japan). Scanning electron microscopy (SEM) analyses were performed using FEI, Quanta 200-ESEM operated at $20 \mathrm{kV}$. X-Ray fluorescence elemental analysis of BC-500 was done using Philips spectrophotometer equipment. The PZC (point zero charge) is the $\mathrm{pH}$ at which the surface has zero net charge; known as $\mathrm{pH}_{\mathrm{pzc}}$ it is characteristic for amphoteric surfaces and affected by the type of surface sites and the structure. For the PZC determination $0.20 \mathrm{~g}$ of BC-20 were mixed with $50 \mathrm{~mL}$ of $0.01 \mathrm{M} \mathrm{NaCl}$ solution for 2 days. The starting solutions $\mathrm{pH}$ (2.0 to 12.0) was adjusted using $\mathrm{HCl}$ and $\mathrm{NaOH}$. After 2 days, the final $\mathrm{pH}$ was measured. The point of zero charge of the $\mathrm{AC}-\mathrm{HP}\left(\mathrm{pH}_{\mathrm{pzc}}\right)$ is the point where the curve $\mathrm{pH}_{\text {final }}$ versus $\mathrm{pH}_{\text {initial }}$ crosses the line $\mathrm{pH}_{\text {initial }}=\mathrm{pH}_{\text {final. }}{ }^{16,35-37}$

\subsection{Adsorbate}

Stock solutions ( $1000 \mathrm{mg} \mathrm{L}^{-1}$ ) of tested adsorbate were prepared by dissolving $p$-nitrophenol (Sigma-Aldrich) in double distilled water and $\mathrm{Pb}^{2+}$ was prepared by dissolving $\mathrm{Pb}\left(\mathrm{NO}_{3}\right)_{2}$ (SigmaAldrich) in $1 \% \mathrm{HNO}_{3}$ solution to avoid hydrolysis formation and precipitation. The working solution was prepared by diluting stock solution to appropriate volumes.

Table 4 Experimental results of lead and p-nitrophenol adsorption using CCD matrix

\begin{tabular}{lrrrll}
\hline & & & & $\begin{array}{l}\text { Lead adsorption } \\
\text { removal\% }\end{array}$ & $\begin{array}{l}p \text {-Nitrophenol } \\
\text { adsorption removal\% }\end{array}$ \\
\hline 1 & -1 & -1 & -1 & 32.52 & 48.23 \\
2 & 1 & -1 & -1 & 80.54 & 72.71 \\
3 & -1 & 1 & -1 & 43.30 & 51.21 \\
4 & 1 & 1 & -1 & 81.62 & 63.62 \\
5 & -1 & -1 & 1 & 36.46 & 45.45 \\
6 & 1 & -1 & 1 & 67.50 & 66.60 \\
7 & -1 & 1 & 1 & 33.41 & 48.48 \\
8 & 1 & 1 & 1 & 58.56 & 56.82 \\
9 & $-\alpha$ & 0 & 0 & 3.44 & 10.20 \\
10 & $\alpha$ & 0 & 0 & 61.47 & 30.21 \\
11 & 0 & $-\alpha$ & 0 & 76.82 & 77.85 \\
12 & 0 & $\alpha$ & 0 & 75.84 & 73.20 \\
13 & 0 & 0 & $-\alpha$ & 73.48 & 88.86 \\
14 & 0 & 0 & $\alpha$ & 52.02 & 80.29 \\
15 & 0 & 0 & 0 & 91.68 & 97.64 \\
16 & 0 & 0 & 0 & 92.92 & 97.74 \\
17 & 0 & 0 & 0 & 91.48 & 96.44
\end{tabular}



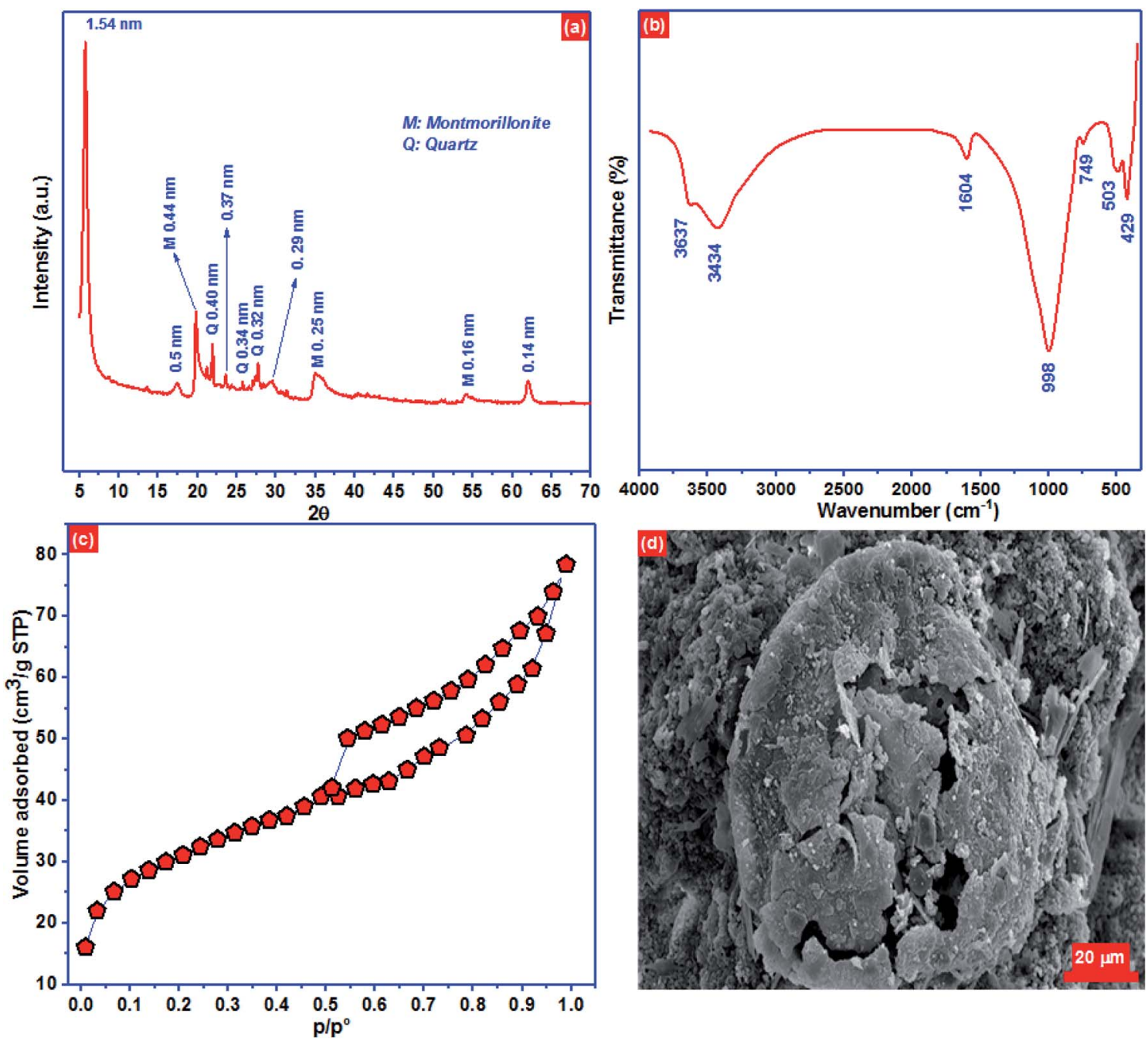

Fig. 1 (a) XRD pattern, (b) FTIR spectra, (c) $\mathrm{N}_{2}$ physisorption isotherm and (d) the surface morphology of BC-500.

\subsection{Adsorption experiments}

Adsorption experiment was executed in duplicate, and the results were averaged. If the bias of the repeated experiment exceeded $15 \%$, a triplicate run was performed.

The influence of the initial $\mathrm{pH}$ on adsorption of $\mathrm{Pb}^{2+}$ and $p$ nitrophenol onto BC-500 was observed by adjusting the $\mathrm{pH}$ value (2.0-12.0) at $20^{\circ} \mathrm{C}$ by using $0.5 \mathrm{M} \mathrm{HCl}$ or $0.5 \mathrm{M} \mathrm{NaOH}$ prior to the experiments. Kinetics essays were carried out at three temperatures $\left(20,40\right.$, and $\left.60{ }^{\circ} \mathrm{C}\right)$ in an Erlenmeyer by mixing $100 \mathrm{mg}$ of $\mathrm{BC}-500$ with $200 \mathrm{~mL}$ of $\mathrm{Pb}^{2+}$ and $p$-nitrophenol solution (concentration of $50 \mathrm{mg} \mathrm{L}^{-1}$ ). The system was constantly shaken in order to keep the mixture's homogeneity and aliquots were collected at different time intervals $\left(\mathrm{Pb}^{2+}: 0-\right.$ $500 \mathrm{~min}$ and $p$-nitrophenol: $0-180 \mathrm{~min}$ ). For adsorption equilibrium studies: various $\mathrm{Pb}^{2+}$ and $p$-nitrophenol solutions with different initial concentration at $20{ }^{\circ} \mathrm{C}\left(5-200 \mathrm{mg} \mathrm{L^{-1 }}\right.$ for $\mathrm{Pb}^{2+}$ and from $10-600 \mathrm{mg} \mathrm{L}^{-1}$ for $p$-nitrophenol). After the specified time, suspensions were filtered through filter paper Whatman 44. The concentration of the supernatant liquid of $\mathrm{Pb}^{2+}$ was determined by the absorption spectrophotometer AA-670.
However, the concentration of $p$-nitrophenol was determined at $\lambda_{\max }=315 \mathrm{~nm}$ using UV-Vis spectrophotometer spectrometry (Shimadzu-2600). Diverse theoretical kinetic and isotherm models are applied to experimental data in order to determine the best-fitting model Table 1 .

\subsection{Response surface methodology (RSM) technique}

Among the methods used to optimize and modeling the adsorption process is the experimental methodology designs, more precisely the optimization by the RSM. ${ }^{15}$ This method has attracted the attention of researchers in recent years. ${ }^{32-34}$ Response surface methodology (RSM) was used to obtain optimum operational parameters. ${ }^{52,53}$ The experimental levels

Table 5 Elementary chemical analysis by X-ray fluorescence

$\begin{array}{lllllllllllll}\mathrm{SiO}_{2} & \mathrm{Al}_{2} \mathrm{O}_{3} & \mathrm{MgO} & \mathrm{Na}_{2} \mathrm{O} & \mathrm{Fe}_{2} \mathrm{O}_{3} & \mathrm{TiO}_{2} & \mathrm{CaO} & \mathrm{K}_{2} \mathrm{O} & \mathrm{P}_{2} \mathrm{O}_{5} & \text { LOI } & \text { Total }\end{array}$

$\begin{array}{lllllllllll}54.11 & 25.62 & 5.12 & 1.02 & 1.20 & 0.29 & 2.62 & 0.20 & 0.03 & 9.48 & 99.69\end{array}$ 

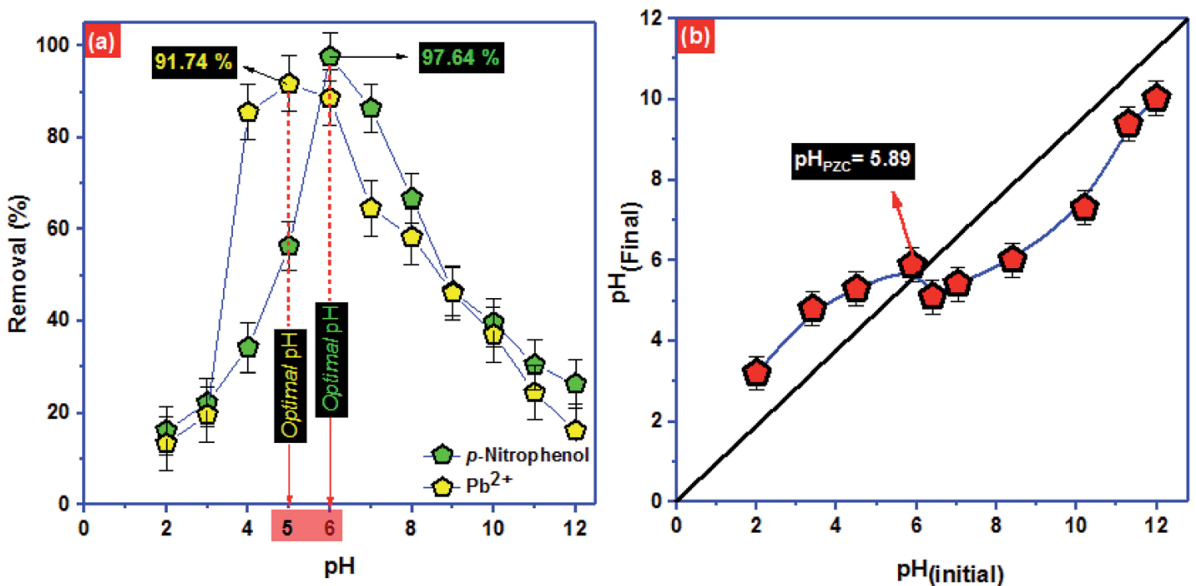

Fig. 2 (a) effect of $\mathrm{pH}$ solution and (b) the point of zero charge $\left(\mathrm{pH}_{\mathrm{pzc}}\right)$ of $\mathrm{BC}-500$.
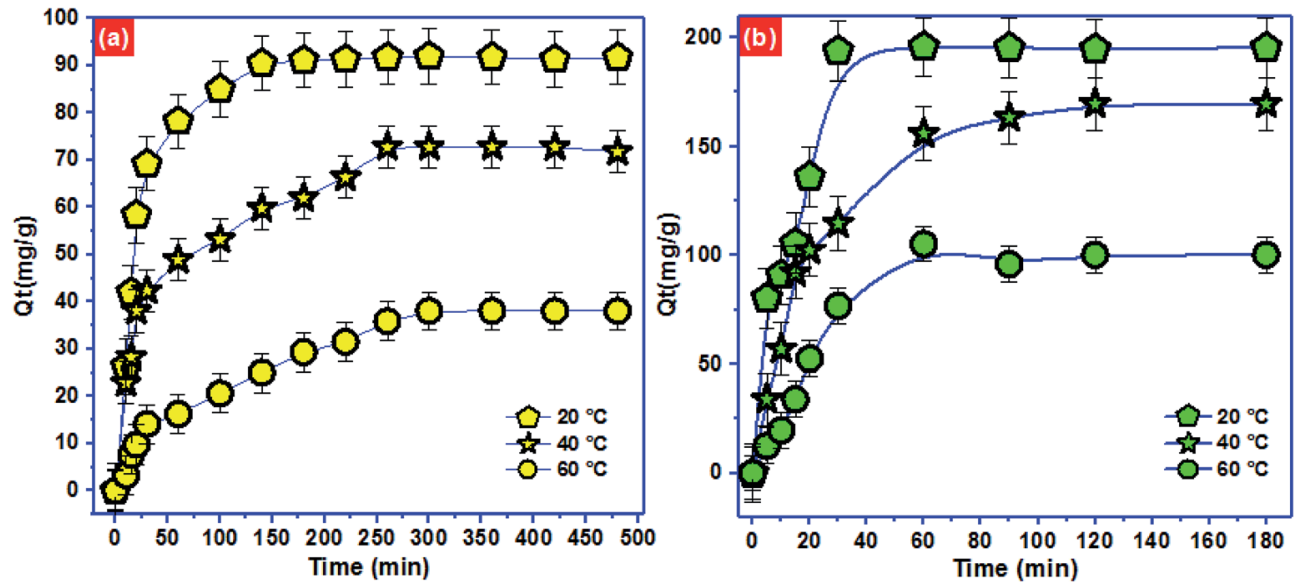

Fig. 3 Effect of contact time and temperature: (a): $\mathrm{Pb}(॥)$; (b): $p$-nitrophenol.

Table 6 Different constants adsorption kinetics

\begin{tabular}{|c|c|c|c|c|c|c|c|c|}
\hline & & \multicolumn{4}{|c|}{ Pseudo-first-order } & \multicolumn{3}{|c|}{ Pseudo-second-order } \\
\hline & $40{ }^{\circ} \mathrm{C}$ & 71.74 & $75.09 \pm 1.76$ & 0.031 & 0.976 & $67.51 \pm 7.12$ & 0.0005 & 0.930 \\
\hline & $60^{\circ} \mathrm{C}$ & 38.04 & $38.78 \pm 1.45$ & 0.008 & 0.982 & $47.90 \pm 2.24$ & 0.0002 & 0.973 \\
\hline$p$-Nitrophenol & $20^{\circ} \mathrm{C}$ & 195.36 & $197.66 \pm 7.29$ & 0.066 & 0.961 & $219.13 \pm 12.07$ & 0.0004 & 0.948 \\
\hline
\end{tabular}

Intraparticle diffusion

\begin{tabular}{lcccc} 
& & $K_{\text {ip }}$ & $C$ \\
\hline $\mathrm{Pb}^{2+}$ & $20^{\circ} \mathrm{C}$ & 3.47 & $33.39 \pm 8.19$ & $18.48 \pm 4.08$ \\
& $40{ }^{\circ} \mathrm{C}$ & 2.99 & $1.079 \pm 1.36$ & 0.705 \\
& $60^{\circ} \mathrm{C}$ & 1.94 & $54.18 \pm 21.22$ & 0.877 \\
-Nitrophenol & $20^{\circ} \mathrm{C}$ & 13.91 & $24.10 \pm 1.78$ & 0.740 \\
& $40^{\circ} \mathrm{C}$ & 13.44 & $5.93 \pm 1.42$
\end{tabular}



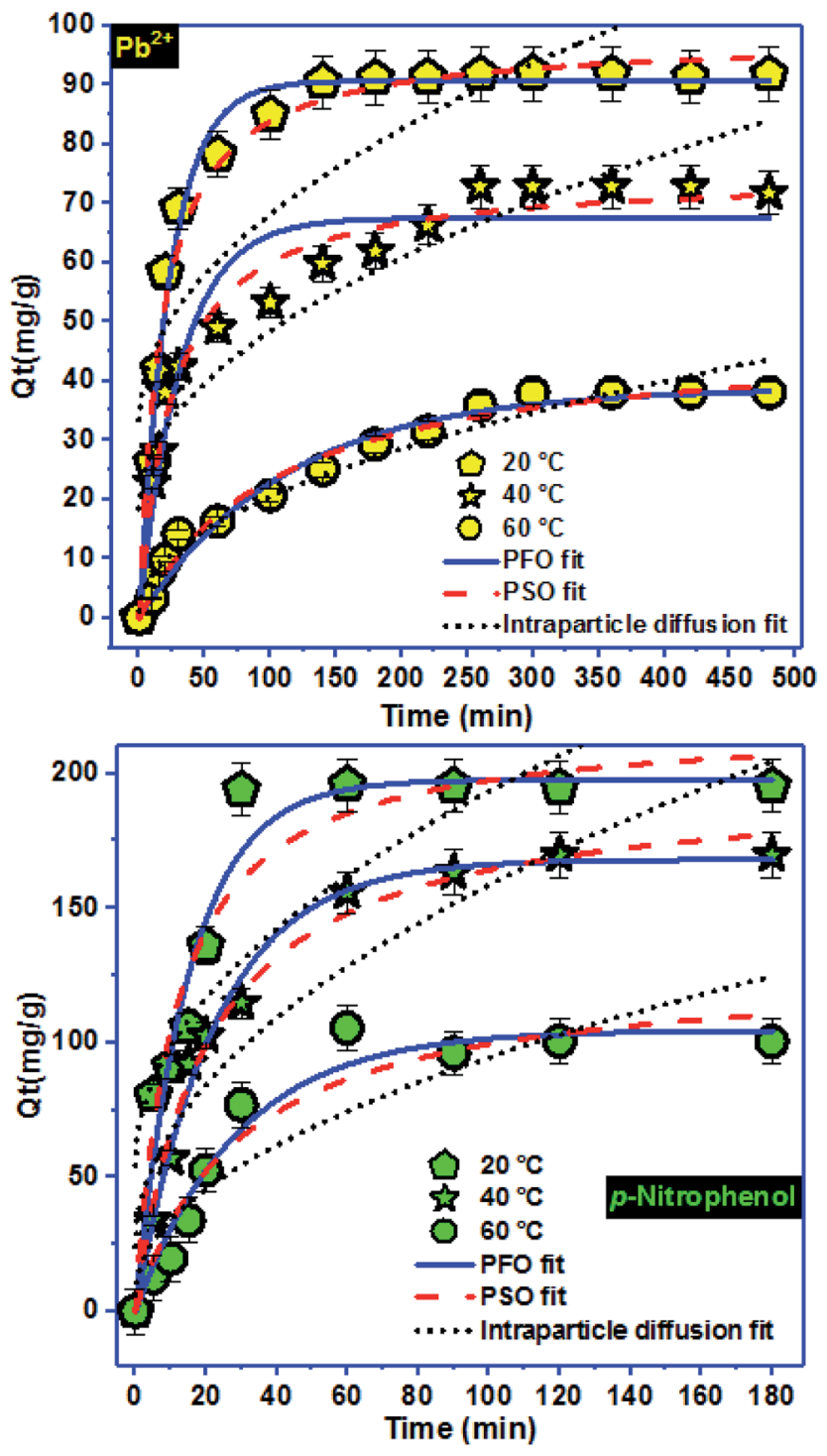

Fig. 4 Non-linear kinetics models adsorption of $\mathrm{Pb}^{2+}$ and $p$-nitrophenol onto BC-500. for lead and $p$-nitrophenol adsorption were presented in Tables 2 and 3, respectively. The experimental results, as well as the CCD matrix, were shown in Table 4 . Therefore, the quadratic polynomial equation that links the response lead and $p$-nitrophenol removal with three studied parameters were presented in equations below.

$$
Y=b_{0}+\sum_{i=1}^{k} b_{i} X_{i}+\sum_{i=1}^{k} b_{i i} X_{1}^{2}+\sum_{i=1}^{k} b_{i j} X_{i} X_{j}
$$

where $Y$ is the predicted response lead or $p$-nitrophenol adsorption, $b_{0}$ is the intercept coefficient, $b_{i}$ the linear terms, $b_{i i}$ the squared terms, $b_{i j}$ the interaction terms, and $X_{1}, X_{2}$ and $X_{3}$ represent the coded independent variables of $\mathrm{pH}$, temperature and concentration, respectively.

\section{Results and discussion}

\subsection{Characterization of $\mathrm{BC}-500$}

XRD pattern of the BC-500 exhibited mostly smectite described by the reflection of $d(001)=1.54 \mathrm{~nm}$ and minor impurities of quartz (Fig. 1a). Moreover, XRD of BC-500 presented the specific reflections consistent to $d$ values of $1.54 \mathrm{~nm}$ (001), $0.50 \mathrm{~nm}$ (003), $0.37 \mathrm{~nm}(004)$ and $0.29 \mathrm{~nm}(005)$ for the basal values for smectites. ${ }^{54}$ However, the reflexion of $d(003)=0.44 \mathrm{~nm}, d(110)$ $=0.25 \mathrm{~nm}$, and $d(210)=0.16 \mathrm{~nm}$ is attributed to the presence of montmorillonite. ${ }^{55,56}$ The reflection of $d(060)=0.14 \mathrm{~nm}$ is linked to a dioctahedral smectite in which the high intensity of $d_{060}$ reflection designated a large size of the coherent domains along the $b$ direction. ${ }^{54,57}$

FTIR spectra can reveal the surface functional groups on BC500 surface qualitatively based on the typical absorbed energy for each bond in certain groups. ${ }^{58}$ The surface functional groups in BC-500 are depicted in Fig. 1b. The peak located at $3637 \mathrm{~cm}^{-1}$ is ascribed to the groups stretching vibrations $\mathrm{OH}$ coordinated octahedral layer to $\mathrm{Al}(\mathrm{Mg})-\mathrm{O}-\mathrm{H} .^{59,60}$ At $3434 \mathrm{~cm}^{-1}$ the peak corresponds to $\mathrm{OH}$ stretching of structural hydroxyl groups. The peak at $1604 \mathrm{~cm}^{-1}$ is associated with $\mathrm{H}-\mathrm{O}-\mathrm{H}$ deformation of water. However, the peaks observed at around 998 and $749 \mathrm{~cm}^{-1}$
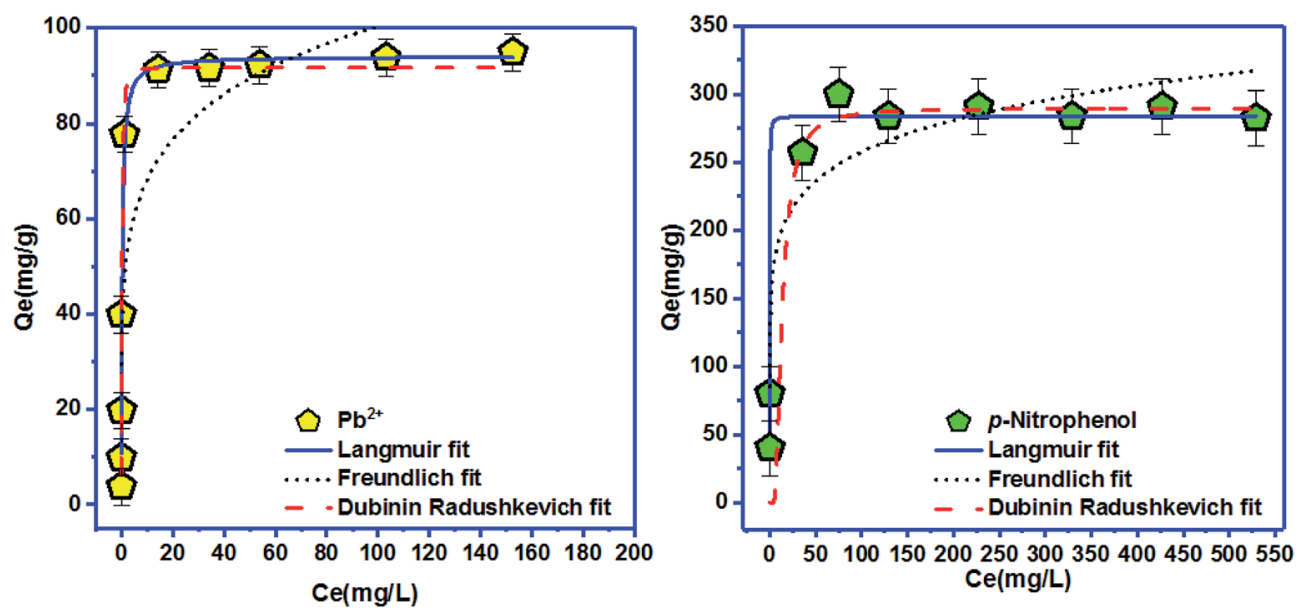

Fig. 5 Non-linear isotherms models used for adsorption of $\mathrm{Pb}^{2+}$ and $p$-nitrophenol onto $\mathrm{BC}-500$. 
Table 7 Isotherms parameters of $\mathrm{Pb}^{2+}$ and $p$-nitrophenol adsorption onto $\mathrm{BC}-500$

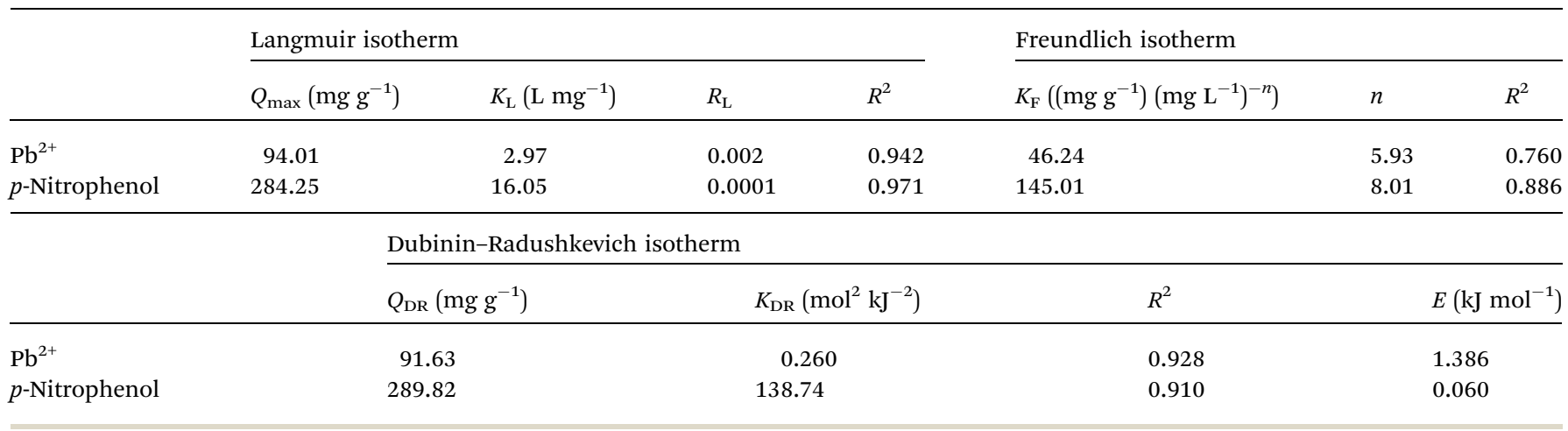

Table 8 Comparison of the maximum adsorption capacity of BC-500 with other adsorbents

\begin{tabular}{llll}
\hline Adsorbent & $\mathrm{Pb}^{2+}$ & $p$-Nitrophenol & Ref. \\
\hline BC-500 & $\mathbf{9 4}$ & $\mathbf{2 8 4}$ & This study \\
Phaseolus hulls activated carbon & 21 & - & 78 \\
Ulva lactuca (AAC) & 83 & - & 79 \\
Apricot stone & 23 & - & 80 \\
Pecan shell & 64 & - & 81 \\
Nano illite/smectite clay & 2 & - & 82 \\
ZnAl-layered double hydroxides & - & 102 & 23 \\
Microporous activated carbon & - & 185 & 25 \\
Hypercrosslinked magnetic & - & 153 & 83 \\
polymer & & & \\
Coal fly ash & - & 11 & 24 \\
$\mathrm{H}_{3} \mathrm{PO}_{3}$-treated coal & - & 256 & 84
\end{tabular}

are linked to $\mathrm{Si}-\mathrm{O}-\mathrm{Si}$ and $\mathrm{Si}-\mathrm{O}$ stretching of silica and quartz. ${ }^{61}$ The peaks at 503 and $429 \mathrm{~cm}^{-1}$ are assigned to $\mathrm{Al}-\mathrm{O}-\mathrm{Si}$ and $\mathrm{Si}-\mathrm{O}$ deformation, respectively. ${ }^{56}$

Nitrogen physisorption isotherm of BC-500 presented in Fig. 1c, represent type IV adsorption isotherm with type H3 hysteresis loops which are characteristics of slit-like pore materials. The noticeable hysteresis loop can be seen on the BC-500 isotherm, signifying the existence of capillary condensation and the presence of mesopores. The BET surface area, total pore volume, and pore size of BC-500 are $101.2 \mathrm{~m}^{2}$ $\mathrm{g}^{-1}, 0.26 \mathrm{~cm}^{3} \mathrm{~g}^{-1}$, and $4.8 \mathrm{~nm}$, respectively. The surface morphology of BC-500 (Fig. 1d) shows porous and heterogeneous structures. This result is also in accord with the specific surface area of BC-500.

Elementary chemical analysis by X-ray fluorescence (Table 5) displays that $\mathrm{Al}_{2} \mathrm{O}_{3}$ and $\mathrm{SiO}_{2}$ are the principal elements with a ratio of $\mathrm{SiO}_{2} / \mathrm{Al}_{2} \mathrm{O}_{3}$ equal to 2.11. This value and the low content of $\mathrm{K}_{2} \mathrm{O}(0.20 \%)$ designate that the $\mathrm{BC}-500$ used in this work belongs to the family of smectite. ${ }^{62}$ Moreover, the existence of exchangeable cations such as $\mathrm{Ca}^{2+}, \mathrm{Na}^{+}$, and $\mathrm{Mg}^{2+}$ indicates that the analyzed BC-500 has a high cation exchange capacity. These outcomes are entirely consistent with those stated by Er-ramly and Ider. ${ }^{63}$

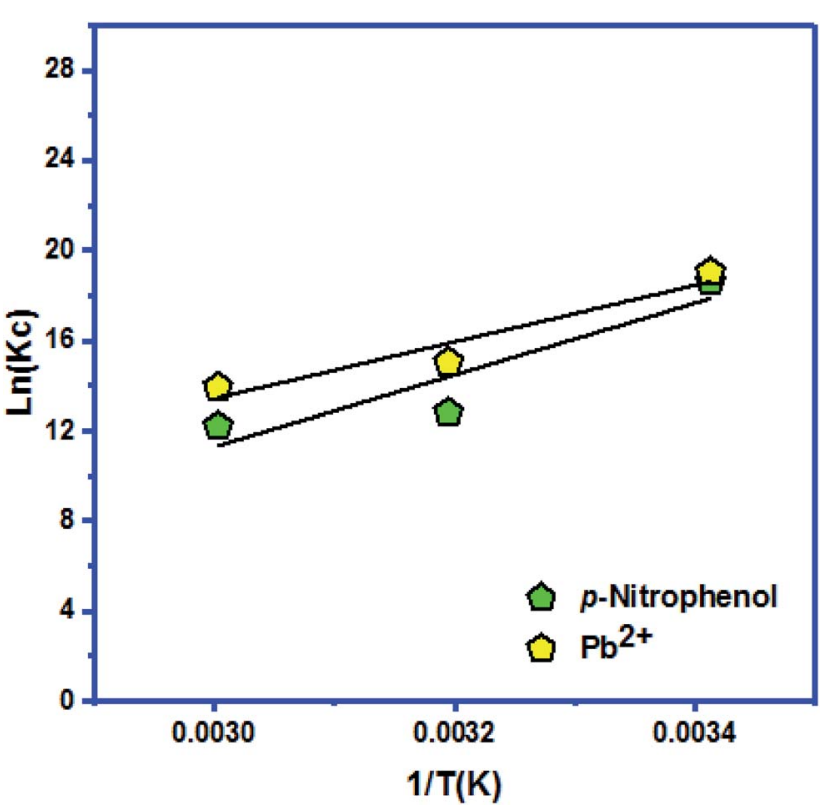

Fig. 6 Van't Hoff plot for $\mathrm{Pb}^{2+}$ and $p$-nitrophenol adsorption onto $\mathrm{BC}$ 500 .

\subsection{Adsorption of $\mathbf{P b}^{2+}$ and $p$-nitrophenol}

3.2.1. Effect of $\mathbf{p H}$. It is well recognized that the $\mathrm{pH}$ of the adsorbate solution plays an essential role in the adsorption process. ${ }^{64-66}$ For additional understanding, we conducted adsorption of $\mathrm{Pb}^{2+}$ and $p$-nitrophenol onto BC-500 at various $\mathrm{pH}$ values.

The removal efficiency increased from 13.4 to $91.74 \%$ for $\mathrm{Pb}^{2+}$ and $16.2-97.64 \%$ for $p$-nitrophenol by increasing the solution $\mathrm{pH}$ from 2.0 to 5.0 for $\mathrm{Pb}^{2+}$ and 2.0 to 6.0 for $p$-nitrophenol. However, the adsorption starts decreasing by 16.2 and $26.4 \%$ at $\mathrm{pH} 12.0$ for $\mathrm{Pb}^{2+}$ and $p$-nitrophenol, respectively (Fig. 2a). The surface of the BC-500 has the point of zero charges $\left(\mathrm{pH}_{\mathrm{pzc}}\right)$ at about 5.89 (Fig. 2b). The decrease in $\mathrm{H}_{3} \mathrm{O}^{+}$with increasing $\mathrm{pH}$ in the acidic solution might increase the electrostatic attraction between the positively charged surface of the BC-500 and the partially negative charge of the $p$-nitrophenol 
Table 9 Thermodynamic parameters for $\mathrm{Pb}^{2+}$ and $p$-nitrophenol adsorption onto BC-500

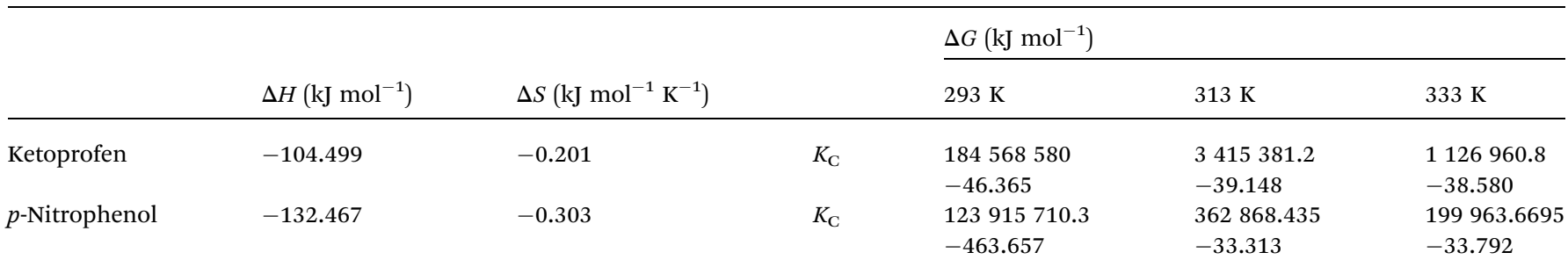

molecules, consequently increasing the adsorption. The BC-500 surface starts to develop a partial negative charge at $\mathrm{pH}$ higher than $\mathrm{pH}_{\mathrm{pzc}}$ (5.89) and the $p$-nitrophenol molecules exists as deprotonated from ( $p$-nitrophenolate anion) at $\mathrm{pH}>\mathrm{p} K_{\mathrm{a}}=$ $7.15,{ }^{67}$ this forms an electrostatic repulsions between the negatively charges $p$-nitrophenol molecules and negative surface of BC-500, which is consistent with previous studies. ${ }^{5,68,69}$

At $\mathrm{pH}$ value between 2.0 to 4.0 , the low removal of $\mathrm{Pb}^{2+}$ may be due to the competition with $\mathrm{H}^{+}$ions on active sites of $\mathrm{BC}-500$. Furthermore, the decrease in the removal efficiency at $\mathrm{pH}$ values (6.0-12.0) might be linked to the formation of $\mathrm{Pb}(\mathrm{OH})_{2}$ and an insoluble precipitate of $\mathrm{Pb}^{2+} \cdot{ }^{20}$ In most of the stated studies regarding heavy metal ions adsorption onto various adsorbent, the adsorption removal displays a maximum for an initial $\mathrm{pH}$ at around $5 .^{70-74}$

3.2.2. Effect of contact time and temperature. Contact time effect was performed in $200 \mathrm{~mL}$ of $\mathrm{Pb}^{2+}$ and $p$-nitrophenol solutions of $50 \mathrm{mg} \mathrm{L}^{-1}$ with varying contact time at optimal $\mathrm{pH}$ and three different temperatures $\left(20,40\right.$, and $\left.60{ }^{\circ} \mathrm{C}\right)$. Fig. 3 displays the effect of different contact times on the adsorption of $\mathrm{Pb}^{2+}$ and $p$-nitrophenol on BC-500. The adsorption was rapid and approximately accomplished (adsorption equilibrium) in 140 min (Fig. 3a) and 30 min (Fig. 3b) at $20^{\circ} \mathrm{C}_{\text {for }} \mathrm{Pb}^{2+}$ and $p$ nitrophenol, respectively. However, increasing temperature influence negatively on adsorption capacity from 92 to $38 \mathrm{mg}$ $\mathrm{g}^{-1}$ in the case of $\mathrm{Pb}^{2+}$ and from 195 to $100 \mathrm{mg} \mathrm{g}^{-1}$ for $p$ - nitrophenol, respectively. This might be related to desorption produced by an increase in the available thermal energy which modify the position of adsorption-desorption equilibrium. ${ }^{66}$ This result shows that a low temperature favours the adsorption of for $\mathrm{Pb}^{2+}$ and $p$-nitrophenol on BC-500.

3.2.3. Adsorption kinetics. The adsorption kinetics of $\mathrm{Pb}^{2+}$ and $p$-nitrophenol onto $\mathrm{BC}-500$ were also examined. Pseudofirst (PFO), second order (PSO), and intraparticle diffusion (IPD) models were employed to correlate the kinetics data (Table 6). Adsorption kinetics data on BC-500 along with the linked model by means of the PFO, PSO, and IPD models were presented in Fig. 4.

To approve the best model that describe the adsorption kinetics of $\mathrm{Pb}^{2+}$ and $p$-nitrophenol onto $\mathrm{BC}-500$, we usually compare the value of correlation coefficients and standard error of estimate (SEE) allowing the correlation between experimental data and the model-predicted values. The nonlinear plots of $\mathrm{Pb}^{2+}$ and $p$-nitrophenol adsorption kinetics and the calculated kinetic parameters are given in Fig. 4 and Table 6. As can be seen, the correlation coefficients found from PFO model was higher compared with $R^{2}$ gotten from PSO model. Additionally, the SEE of PFO model was the lowest one compared to PSO model. Consequently, PFO model describe well the adsorption data of $\mathrm{Pb}^{2+}$ and $p$-nitrophenol onto BC-500 at all studied temperature. Besides, the experimental adsorption capacity of $\mathrm{Pb}^{2+}$ and $p$-nitrophenol onto BC-500 were very close to the calculated one by PFO model (Table 6).
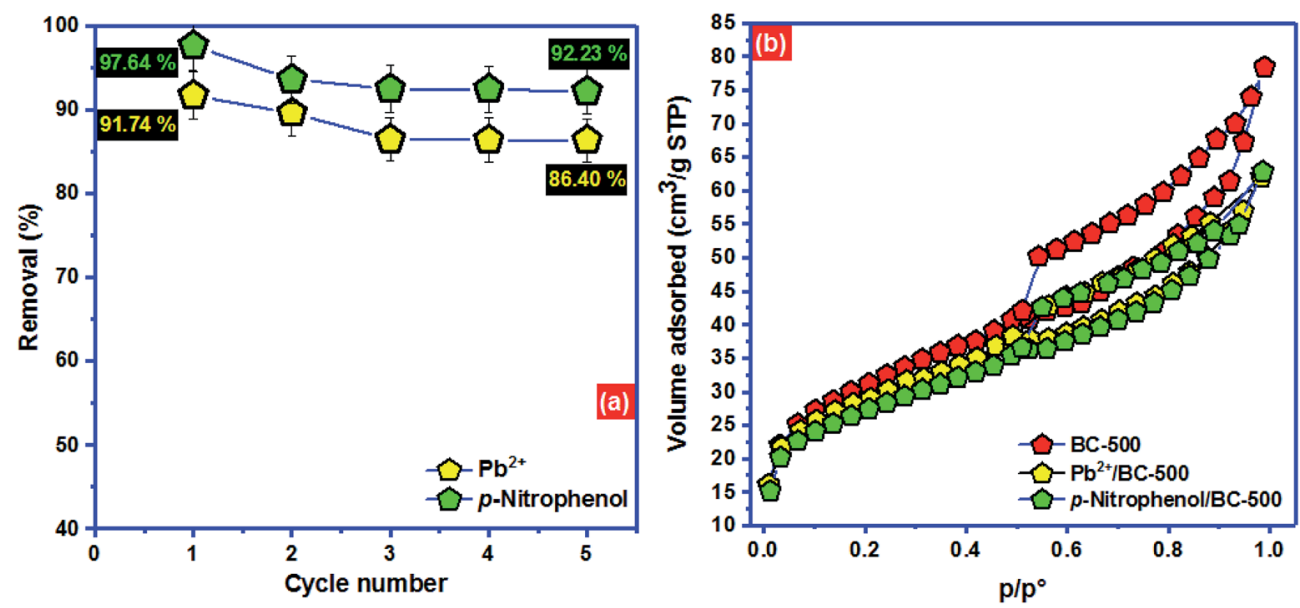

Fig. 7 (a) Regeneration of $\mathrm{BC}-500$ and (b) adsorption mechanism of $\mathrm{Pb}^{2+}$ and $p$-nitrophenol onto $\mathrm{BC}-500$. 
Table 10 ANOVA analyses

\begin{tabular}{|c|c|c|}
\hline NOM & Coefficient & $P$-value \\
\hline \multicolumn{3}{|c|}{ Lead adsorption } \\
\hline Model & - & $<0.0001$ \\
\hline b0 & 92.081 & $<0.0001$ \\
\hline b1 & 17.583 & $<0.0001$ \\
\hline b2 & -0.130 & 0.709 \\
\hline b3 & -5.722 & $<0.0001$ \\
\hline b1-1 & -21.246 & $<0.0001$ \\
\hline b2-2 & -5.733 & $<0.0001$ \\
\hline b3-3 & -10.535 & $<0.0001$ \\
\hline b1-2 & -1.949 & 0.00293 \\
\hline b1-3 & -3.769 & $<0.0001$ \\
\hline b2-3 & -2.981 & 0.000248 \\
\hline Lack of fit & & 0.26 \\
\hline$R^{2}$ & 0.999 & \\
\hline$R_{\mathrm{Adj}}^{2}$ & 0.998 & \\
\hline \multicolumn{3}{|c|}{$p$-Nitrophenol adsorption } \\
\hline Model & - & $<0.0001$ \\
\hline b0 & 53.532 & $<0.0001$ \\
\hline b1 & 17.249 & $<0.0001$ \\
\hline b2 & 10.802 & 0.0200 \\
\hline b3 & 8.605 & 0.0206 \\
\hline b1-1 & -2.998 & $<0.0001$ \\
\hline $\mathrm{b} 2-2$ & -2.689 & $<0.0001$ \\
\hline b3-3 & -4.416 & $<0.0001$ \\
\hline b1-2 & -0.720 & 0.0218 \\
\hline b1-3 & -2.542 & 0.2040 \\
\hline b2-3 & -4.090 & 0.9070 \\
\hline Lack of fit & & 0.104 \\
\hline$R^{2}$ & 0.997 & \\
\hline$R_{\mathrm{Adj}}^{2}$ & 0.994 & \\
\hline
\end{tabular}

In other hand, the increase in temperature decrease the acceleration of $\mathrm{Pb}^{2+}$ and $p$-nitrophenol adsorption on $\mathrm{BC}-500$, which was certificated by the decrease in the second-order rate constants $\left(K_{2}\right)$. This might be due to the increase of solution viscosity at high temperature and thus diminish the mass transfer and diffusion of the $\mathrm{Pb}^{2+}$ and $p$-nitrophenol inside $\mathrm{BC}$ 500.

Moreover, Fig. 4 displays the curve-fitting plots of IPD model for $\mathrm{Pb}^{2+}$ and $p$-nitrophenol onto $\mathrm{BC}-500$ adsorption. The values of the intercept $\mathrm{C}$ of $\mathrm{Pb}^{2+}$ and $p$-nitrophenol give an idea about the boundary layer thickness: the larger intercept, the greater is the boundary layer effect in adsorption by BC-500. In the meantime, the plots do not pass over the origin, this specifies that there lies some degree of boundary layer control and the IPD is not the lonely rate-controlling step, but also other processes may control the rate of adsorption of $\mathrm{Pb}^{2+}$ and $p$ nitrophenol. ${ }^{75}$ Hence, the IPD model is not appropriate for describing the $\mathrm{Pb}^{2+}$ and $p$-nitrophenol removal from water onto BC-500. It can be concluding that the PFO model described well the kinetics data of $\mathrm{Pb}^{2+}$ and $p$-nitrophenol compared to $\mathrm{PFO}$ and IPD models.

3.2.4. Adsorption isotherms. To investigate the most suitable correlation for the equilibrium data of $\mathrm{Pb}^{2+}$ and $p$-nitrophenol adsorption onto BC-500 (Fig. 5), three non-linear models were used, Langmuir, Freundlich, and Dubinin-Radushkevich (D-R). The calculated values for Langmuir, Freundlich, and Dubinin-Radushkevich parameters were summarized in Table 4. From Table 4, the adsorption of $\mathrm{Pb}^{2+}$ and $p$-nitrophenol onto BC-500 were well fitted to the Langmuir isotherm model with high $R^{2}$, which endorse the homogeneous distribution of active sites on the surface of BC-500. ${ }^{4}$ In addition, the nature of the adsorption process on $\mathrm{BC}-500$ was investigated by calculating the values of $R_{\mathrm{L}}$ and Freundlich constant $n$. As a result, the adsorption $\mathrm{Pb}^{2+}$ and $p$-nitrophenol onto BC-500 were favorable $\left(R_{\mathrm{L}}\right.$ between 0 and 1 , and $1 / n$ parameter was smaller than 1$) .{ }^{17}$ Based on Langmuir isotherm (Table 7), the maximum adsorption capacities $Q_{\max }$ was equal $94.01 \mathrm{mg} \mathrm{g}^{-1}$ (for $\mathrm{Pb}^{2+}$ adsorption) and $284.25 \mathrm{mg} \mathrm{g}^{-1}$ (for $p$-nitrophenol adsorption).

To elucidate the physical and chemical adsorption nature of $\mathrm{Pb}^{2+}$ and $p$-nitrophenol onto BC-500, Langmuir and Freundlich isotherms are insufficient, for this purpose D-R isotherm is
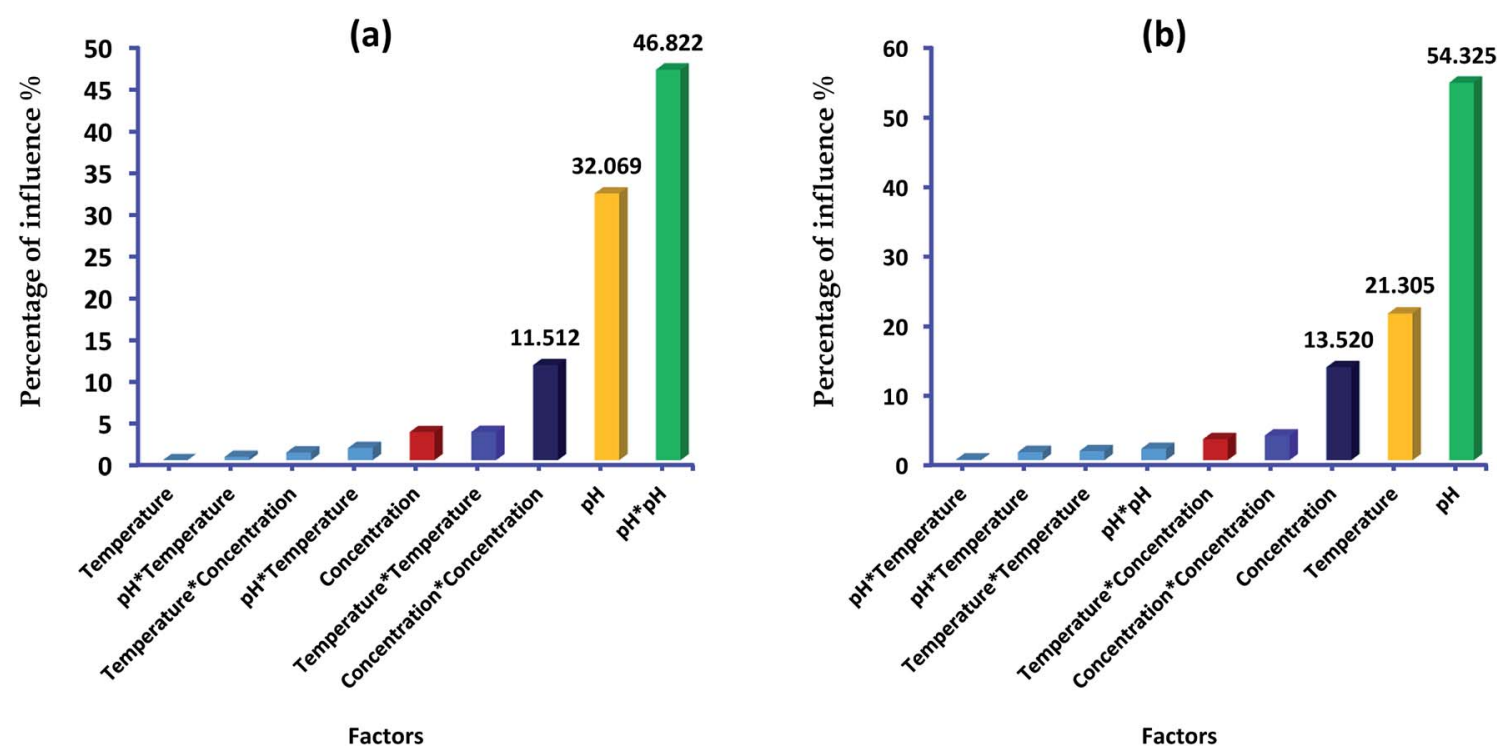

Fig. 8 Pareto chart for (a) lead and (b) p-nitrophenol adsorption. 

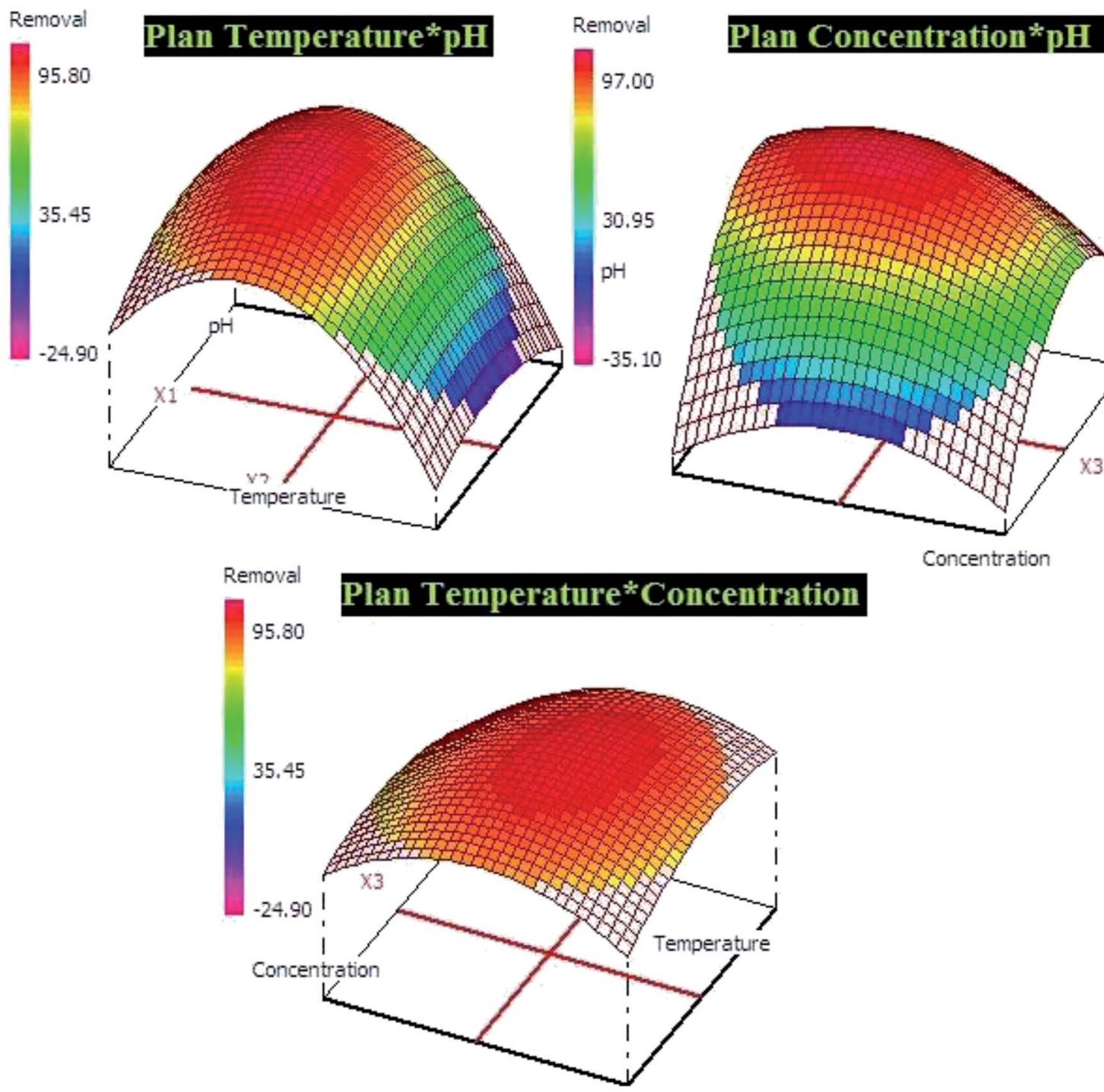

Fig. 9 RSM presentations for lead adsorption on different possible plans.

normally used..$^{30}$ The mean free energy of adsorption $E_{\mathrm{DR}}\left(E_{\mathrm{DR}}\right.$ of transference for $1 \mathrm{~mol}$ of solute from solution to the surface of CB-500 (ref. 76)), for $\mathrm{Pb}^{2+}$ and $p$-nitrophenol adsorption onto $\mathrm{BC}-500$ was found equal to $1.386 \mathrm{~kJ} \mathrm{~mol}^{-1}$ (for $\mathrm{Pb}^{2+}$ adsorption) and $0.060 \mathrm{~kJ} \mathrm{~mol}^{-1}$ (for $p$-nitrophenol adsorption) (Table 7). These values are matching with other earlier studies using natural clay for adsorption in aqueous solutions. ${ }^{30}$ Following the D-R isotherm model, $|E|$ values between 1$8 \mathrm{~kJ} \mathrm{~mol}^{-1}$ specify that the adsorption is a physical process, whereas, when $|E|$ are between $8.0 \mathrm{~kJ} \mathrm{~mol}^{-1}$ and $16 \mathrm{~kJ} \mathrm{~mol}^{-1}$ the adsorption occurs at an ion-exchange-type surface. ${ }^{77}$ In our study, $\mathrm{Pb}^{2+}$ and $p$-nitrophenol adsorption onto $\mathrm{BC}-500$, we found the values of $E_{\mathrm{DR}}$ is in the range of $1-8 \mathrm{~kJ} \mathrm{~mol}^{-1}$, and consequently, mean that in our case the adsorption occurs via a physical process on BC-500. The adsorption capacity of BC500 is compared to several adsorbents presented in Table 8. We found that the sorption capacity of BC-500 is better compared to others adsorbents.
3.2.5. Thermodynamic parameters. The comportment of adsorption (i.e., physical or chemical) can be understood over the study of adsorption thermodynamics. The thermodynamic parameters $\left(\Delta G^{\circ}, \Delta H^{\circ}\right.$, and $\left.\Delta S^{\circ}\right)$ can be calculated by the Van't Hoff approach..$^{50,85}$ The Van't Hoff equation and Gibbs energy equations (Table 9) were used to calculate the thermodynamic parameters of $\mathrm{Pb}^{2+}$ and $p$-nitrophenol adsorption on $\mathrm{BC}-500$ (Fig. 6). From Table 9, the negative $\Delta G^{\circ}$ values at all studied temperatures for $\mathrm{Pb}^{2+}$ and $p$-nitrophenol stipulate that the adsorption occurrence occurred spontaneously. Furthermore, the negative $\left(-\Delta S^{\circ}\right)$ values disclose that the organization of $\mathrm{Pb}^{2+}$ and $p$-nitrophenol at the solid/solution interface through the adsorption process on BC-500 develops less random when the temperature increases. A negative value of $\Delta H^{\circ}$ indicate that the adsorption process occurred exothermically. An exothermic process is obviously related to physical adsorption (physisorption) with the occurrence of relatively weak interactions (i.e., van der Waals force). ${ }^{86}$ 


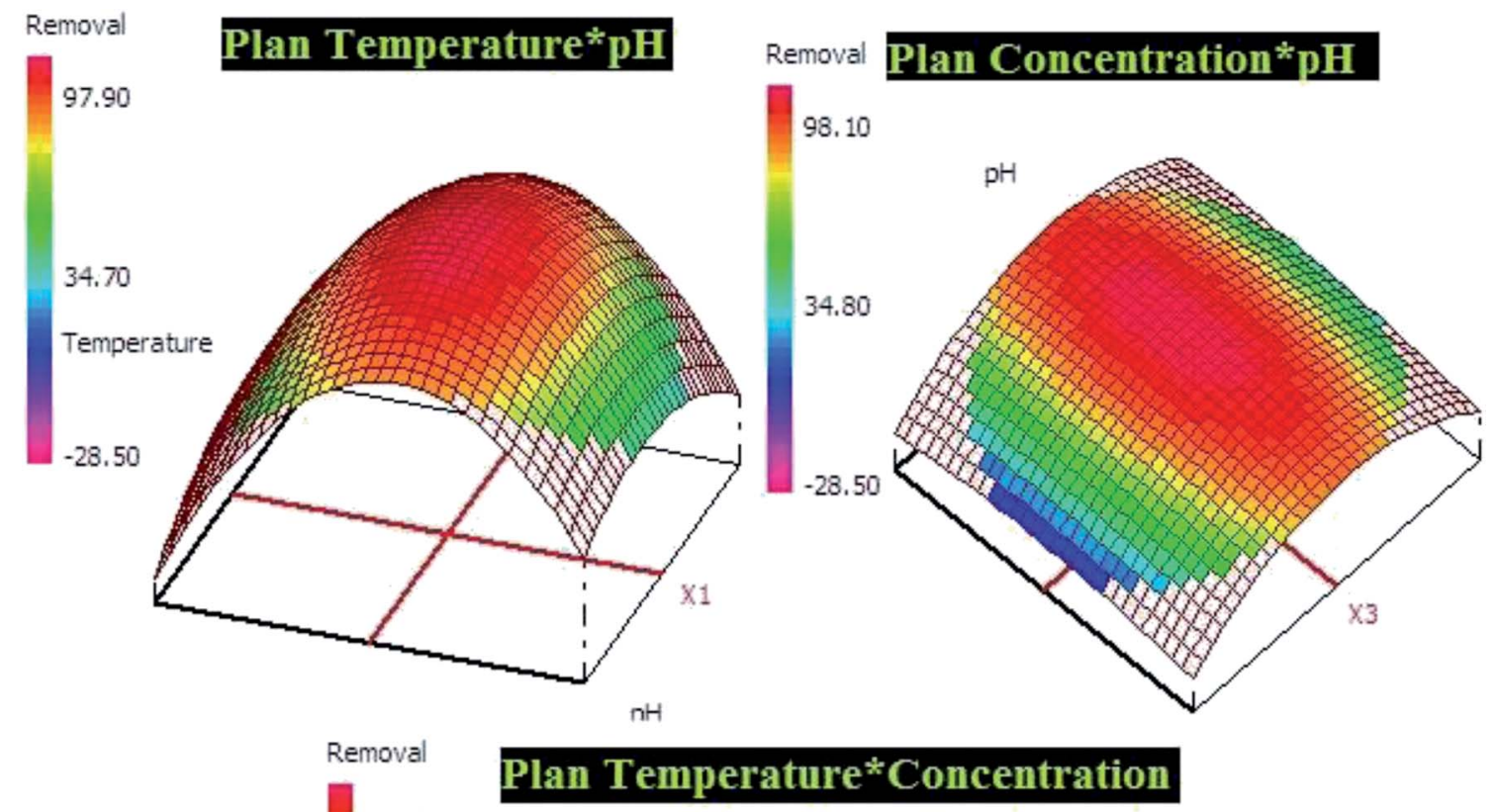

97.90

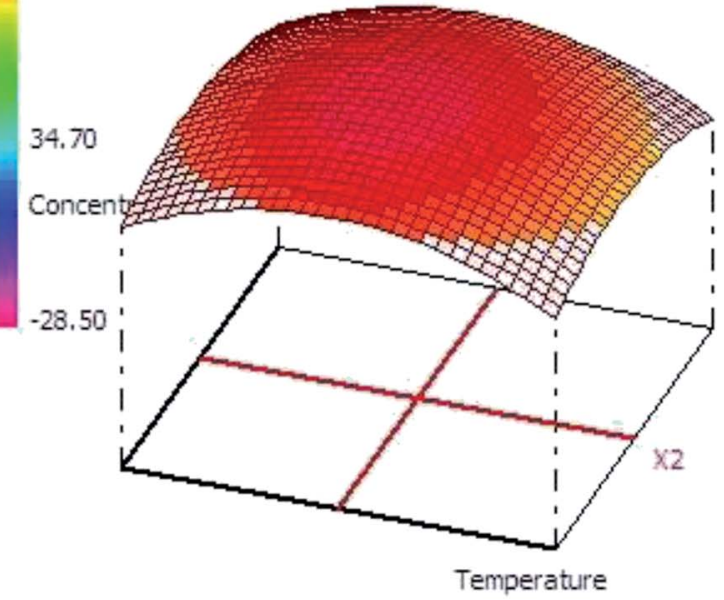

Fig. 10 RSM presentations for $p$-nitrophenol adsorption on different possible plans.

3.2.6. Regeneration of $\mathrm{BC}-500$ and adsorption mechanism. Renewability is an essential concern to evaluate the adsorbent performance for wastewater treatment. ${ }^{\mathbf{1 4 8 7}}$ In order to distinguish the renewability of BC-500, the used BC-500 was washed out and then reused in the new experiments to evaluate its cycle performance. In this work, $0.5 \mathrm{M} \mathrm{HCl}$ and ethanol were used for $\mathrm{Pb}^{2+} / \mathrm{BC}-500$ and $p$-nitrophenol/BC-500 regeneration, respectively. The outcomes are illustrated in Fig. 7a. The $\mathrm{Pb}^{2+} / \mathrm{BC}-500$ regenerated by $0.5 \mathrm{M} \mathrm{HCl}$ revealed a slight decrease $(-5.82 \%)$ from $91.74 \%$ to 86.40 after 5 cycles. Likewise, the $p$-nitrophenol/ BC-500 regenerated by ethanol-exposed a small decreased $(-5.54 \%)$. This suggests that BC-500 is an outstanding recycling adsorption material.

To advance the investigation of adsorption comportment of $\mathrm{Pb}^{2+}$ and $p$-nitrophenol onto BC-500, Fig. 7b displays the nitrogen physisorption isotherm for $\mathrm{BC}-500$ before and after adsorption of $\mathrm{Pb}^{2+}$ and $p$-nitrophenol. After the adsorption of
$\mathrm{Pb}^{2+}$ and $p$-nitrophenol onto BC-500, the surface area decreases noticeably from 101.2 to $94.4 \mathrm{~m}^{2} \mathrm{~g}^{-1}$ and from 101.2 to $88.6 \mathrm{~m}^{2}$ $\mathrm{g}^{-1}$, respectively. The total pore volume also diminishes from 0.26 to $0.19 \mathrm{~cm}^{3} \mathrm{~g}^{-1}$ for $\mathrm{Pb}^{2+} / \mathrm{BC}-500$ and from 0.26 to $0.14 \mathrm{~cm}^{3}$ $\mathrm{g}^{-1}$, which proves that the adsorbed $\mathrm{Pb}^{2+}$ and $p$-nitrophenol choose to be stored in the pores of BC-500 which is consistent with the outcomes of Dubinin-Radushkevich model.

3.2.7. Optimization of adsorption by response surface methodology (RSM). In this part of work, response surface methodology technique was used to optimize the adsorption process of $\mathrm{Pb}^{2+}$ and $p$-nitrophenol in order to modelled the reaction pathways taking into account the influence of different parameters as a function of lead and $p$-nitrophenol removal efficiency onto BC-500. ${ }^{\mathbf{8 8 , 8 9}}$ Therefore, the analysis of variance results (ANOVA) for lead or $p$-nitrophenol adsorption were presented in Table 10. Based on this statically analysis we conclude that: 
Table 11 Experimental and predicted removal by the model for lead and $p$-nitrophenol adsorption

Adsorption of lead $\left(\mathrm{pH}=5.0\right.$, temperature $=20.0{ }^{\circ} \mathrm{C}$, concentration $=$ $50.0 \mathrm{mg} \mathrm{L}^{-1}$ )

Predicted

Experimental

$91.28 \pm 1.68$

$90.93 \pm 2.15$

Adsorption of $p$-nitrophenol $\left(\mathrm{pH}=6.0\right.$, temperature $=20.0^{\circ} \mathrm{C}$, concentration $=50.0 \mathrm{mg} \mathrm{L}^{-1}$ )

Predicted

Experimental

$97.24 \pm 2.54$

$98.06 \pm 1.87$

- The term ' $P$-value' less than 0.05 implies that designed model is significant for both lead or $p$-nitrophenol.

- The correlation coefficient $\left(R^{2}\right)$ and the adjusted correlation coefficient $\left(R_{\mathrm{Adj}}{ }^{2}\right)$ prove the existence of a good correlation between data.

- The coefficients significations of models were studied at the $5 \%$ confidence level and their $P$-values less than 0.05 , except b2 for lead adsorption and b2-1, b1-3 for $p$-nitrophenol adsorption.

In addition, Pareto diagram presented in Fig. 8 indicates that the parameters including square effect of $\mathrm{pH}, \mathrm{pH}$ and square effect of concentration represent more than $90 \%$ of response variation in the case of lead adsorption. In the case of $p$-nitrophenol adsorption, $\mathrm{pH}$, temperature and concentration influence the removal efficiency by $54.03 \%, 21.30 \%$ and 13.52 , respectively. As results, Pareto analysis showed that the influence of $\mathrm{pH}$ was very high compared with other factors in both systems, which confirms the effect of electrostatic attractions mechanism during the adsorption of lead and $p$-nitrophenol.

The developed models for lead or $p$-nitrophenol adsorption were giving below using the quadratic polynomial equation.

$$
\begin{gathered}
R \%(\text { lead })=92.081+17.583 X_{\mathrm{pH}}-5.722 X_{\text {concentration }}- \\
21.246 X_{\mathrm{pH}} \times X_{\mathrm{pH}}-5.733 X_{\mathrm{Temperature}} \times X_{\text {Temperature }}- \\
10.535 X_{\text {concentration }} \times X_{\text {concentration }}-1.949 X_{\mathrm{pH}} \times X_{\text {concentration }}- \\
3.769 X_{\mathrm{pH}} \times X_{\text {concentration }}-2.981 X_{\text {concentration }} \times X_{\text {Temperature }} \\
R \%(p \text {-nitrophenol })=53.532+17.249 X_{\mathrm{pH}}+10.802 X_{\text {Temperature }}+ \\
8.605 X_{\text {concentration }}-2.998 X_{\mathrm{pH}} \times X_{\mathrm{pH}}-2.689 X_{\text {Temperature }} \times \\
X_{\text {Temperature }}-4.416 X_{\text {concentration }} \times X_{\text {concentration }}-0.720 X_{\mathrm{pH}} \times \\
X_{\text {Temperature }}-2.542 X X_{\mathrm{pH}} \times X_{\text {concentration }}-4.090 X_{\text {concentration }} \times \\
X_{\text {Temperature }}
\end{gathered}
$$

The both equations were used to elaborate the response surfaces which allows to obtain the optimization parameters of lead and $p$-nitrophenol adsorption and well understood the process (Fig. 9 and 10). Based on RSM presentation, the optimum conditions in term of lead and $p$-nitrophenol removal were showed in Table 11. Under these conditions the experimental and predicted removal by the obtained model showing a high correlation, which indicate the importance of this study in terms of modeling and optimization.

\section{Conclusion}

In this study, BC-500 as the low-cost adsorbent is talented to remove $\mathrm{Pb}^{2+}$ and $p$-nitrophenol from contaminated water very efficiently. The adsorption kinetic studies demonstrate that the removal of $\mathrm{Pb}^{2+}$ and $p$-nitrophenol is a rapid process and the adsorption process follows the pseudo-first-order model, demonstrating that $\mathrm{Pb}^{2+}$ and $p$-nitrophenol has a strong affinity on the BC-500 surface. It was found that the experimental isotherm data can be tailored well to the Langmuir equilibrium equation and BC-500 has very high $\mathrm{Pb}^{2+}$ and $p$-nitrophenol adsorption capacity of approximately $94 \mathrm{mg} \mathrm{g}^{-1}$ and $284 \mathrm{mg} \mathrm{g}^{-1}$ at $20^{\circ} \mathrm{C}$, respectively. Increasing temperature $\left(20-60^{\circ} \mathrm{C}\right)$ has an effect negative on adsorption capacity $\mathrm{Pb}^{2+}$ and $p$-nitrophenol. The removal of $\mathrm{Pb}^{2+}$ and $p$-nitrophenol depend clearly on the $\mathrm{pH}$ of the solution. The study on adsorption mechanism displays that the adsorption of $\mathrm{Pb}^{2+}$ and $p$-nitrophenol on $\mathrm{BC}$ 500 is dominated by physisorption process. Finally, the optimized parameters by the RSM method showed a good agreement between the predicted and experimental results.

\section{Conflicts of interest}

Authors declare that they have no conflict of interest.

\section{Acknowledgements}

This work was supported by the Ibn Zohr University, Faculty of Sciences-Morocco.

\section{References}

1 T. S. Anirudhan and M. Ramachandran, J. Colloid Interface Sci., 2006, 299, 116-124.

2 T. S. Anirudhan and M. Ramachandran, Process Saf. Environ. Prot., 2015, 95, 215-225.

3 A. H. Jawad, R. A. Rachid, M. A. M. Ishak and L. D. Wilson, Desalin. Water Treat., 2016, 1, 25194-25206.

4 L. Wang, J. Zhang, R. Zhao, Y. Li, C. Li and C. Zhang, Bioresour. Technol., 2010, 101, 5808-5814.

5 B. Zhang, F. Li, T. Wu, D. Sun and Y. Li, Colloids Surf., A, 2015, 464, 78-88.

6 A. dos Santos, M. F. Viante, D. J. Pochapski, A. J. Downs and C. A. P. Almeida, J. Hazard. Mater., 2018, 355, 136-144.

7 S. Dutta, J. K. Basu and R. N. Ghar, Sep. Purif. Technol., 2001, 21, 227-235.

8 S. Haydar, M. A. Ferro-García, J. Rivera-Utrilla and J. P. Joly, Carbon, 2003, 41, 387-395.

9 W. S. W. Ngah and S. Fatinathan, J. Environ. Manage., 2010, 91, 958-969.

10 S. S. Tahir and R. Naseem, Sep. Purif. Technol., 2007, 53, 312321.

11 H. N. Tran, C.-C. Lin and H.-P. Chao, Sep. Purif. Technol., 2018, 192, 36-45. 
12 H. J. He, Z. H. Xiang, X. J. Chen, H. Chen, H. Huang, M. Wen and C. P. Yang, Int. J. Environ. Sci. Technol., 2018, 15, 14911500 .

13 M. Zbair, Z. Anfar, H. Khallok, H. A. Ahsaine, M. Ezahri and N. Elalem, Fullerenes, Nanotubes, Carbon Nanostruct., 2018, 26, 433-442.

14 Z. Anfar, M. Zbair, H. A. Ahsaine, M. Ezahri and N. El Alem, Fullerenes, Nanotubes, Carbon Nanostruct., 2018, 26, 389-397.

15 M. Zbair, Z. Anfar, H. A. Ahsaine, N. El Alem and M. Ezahri, J. Environ. Manage., 2018, 206, 383-397.

16 M. Zbair, H. A. Ahsaine and Z. Anfar, J. Cleaner Prod., 2018, 202, 571-581.

17 Z. Anfar, R. El Haouti, S. Lhanafi, M. Benafqir, Y. Azougarh and N. El Alem, J. Environ. Chem. Eng., 2017, 5, 5857-5867.

18 H. Ait Ahsaine, M. Zbair, Z. Anfar, Y. Naciri, R. El haouti, N. El Alem and M. Ezahri, Mater. Today Chem., 2018, 8, 1-12.

19 I. Anastopoulos, A. Bhatnagar, B. Hameed, Y. S. Ok and M. Omirou, J. Mol. Liq., 2017, 240, 179-188.

20 L. Bulgariu and D. Bulgariu, J. Cleaner Prod., 2018, 197, 875885.

21 Y. Huang, C. Yang, Z. Sun, G. Zeng and H. He, RSC Adv., 2015, 5, 11475-11484.

22 C. Yan, Y. Chunping, H. Huijun, Z. Guangming, Z. Kun and Y. Zhou, J. Environ. Eng., 2016, 142, C4015001.

23 Q. Zhang, C. Peter Okoli, L. Wang and T. Liang, Desalin. Water Treat., 2015, 55, 1575-1585.

24 B. Liu, F. Yang, Y. Zou and Y. Peng, J. Chem. Eng. Data, 2014, 59, 1476-1482.

$25 \mathrm{M}$. Ahmed and S. Theydan, Adsorptive removal of $p$ nitrophenol on microporous activated carbon by $\mathrm{FeCl}_{3}$ activation: equilibrium and kinetics studies, 2014, vol. 55.

26 A. Sari, M. Tuzen and M. Soylak, J. Hazard. Mater., 2007, 144, 41-46.

27 G. Bereket, A. Z. Aroğuz and M. Z. Özel, J. Colloid Interface Sci., 1997, 187, 338-343.

28 M. Tuzen, E. Melek and M. Soylak, J. Hazard. Mater., 2006, 136, 597-603.

29 N. L. D. Filho, W. L. Polito and Y. Gushikem, Talanta, 1995, 42, 1031-1036.

30 S. Veli and B. Alyüz, J. Hazard. Mater., 2007, 149, 226-233.

31 S. S. Tahir and N. Rauf, Chemosphere, 2006, 63, 1842-1848.

32 K. Zhao, Y. Cheng, H. Liu, C. Yang, L. Qiu, G. Zeng and H. He, $R S C A d v$. , 2015, 5, 66013-66023.

33 L. Qiu, Y. Cheng, C. Yang, G. Zeng, Z. Long, S. Wei, K. Zhao and L. Luo, RSC Adv., 2016, 6, 17036-17045.

34 C. Yang, K. Zhao, Y. Cheng, G. Zeng, M. Zhang, J. Shao and L. Lu, Sep. Purif. Technol., 2016, 163, 153-161.

35 T. K. M. Prashantha Kumar, T. R. Mandlimath, P. Sangeetha, P. Sakthivel, S. K. Revathi, S. K. Ashok Kumar and S. K. Sahoo, RSC Adv., 2015, 5, 108034-108043.

36 D. Mohan, A. Sarswat, V. K. Singh, M. Alexandre-Franco and C. U. Pittman Jr, Chem. Eng. J., 2011, 172, 1111-1125.

37 J. S. Noh and J. A. Schwarz, J. Colloid Interface Sci., 1989, 130, 157-164.

38 J. Wang, C. P. Huang, H. E. Allen, D. K. Cha and D. W. Kim, J. Colloid Interface Sci., 1998, 208, 518-528.
39 V. K. Garg, R. Gupta, A. B. Yadav and R. Kumar, Bioresour. Technol., 2003, 89, 121-124.

40 S. Lagergren, K. Sven. Vetenskapsakad. Handl., 1898, 24, 1.

41 G. McKay, Process Biochem., 1999, 34, 451.

42 J. C. Weber and W. J. Morris, J. Sanit. Eng. Div., Am. Soc. Civ.

Eng., 1963, 89, 31-60.

43 I. Langmuir, J. Am. Chem. Soc., 1916, 38, 2221-2295.

44 S. Fan, Y. Wang, Z. Wang, J. Tang, J. Tang and X. Li, J.

Environ. Chem. Eng., 2017, 5, 601-611.

45 H. Freundlich, Z. Phys. Chem., 1906, 57, 385.

46 L. V. Dubinin and M. M. Radushkevich, Proc. Acad. Sci. USSR,

Phys. Chem. Sect., 1947, 55, 331-333.

47 G. F. Cerofolini, Surf. Sci., 1975, 51, 333-335.

48 M. Ghasemi, M. Naushad, N. Ghasemi and Y. Khosravi-fard,

J. Ind. Eng. Chem., 2014, 20, 2193-2199.

49 E. C. Lima, A. Hosseini-Bandegharaei, J. C. Moreno-Piraján and I. Anastopoulos, J. Mol. Liq., 2019, 273, 425-434.

50 I. Anastopoulos and G. Z. Kyzas, J. Mol. Liq., 2016, 218, 174185.

51 P. S. Ghosal and A. K. Gupta, J. Mol. Liq., 2017, 225, 137-146. 52 Z. Anfar, M. Zbair, H. A. Ahsaine, M. Ezahri and N. E. Alem, Fullerenes, Nanotubes, Carbon Nanostruct., 2018, 26, 389-397.

53 M. Zbair, K. Ainassaari, Z. El Assal, S. Ojala, N. El Ouahedy, R. L. Keiski, M. Bensitel and R. Brahmi, Environ. Sci. Pollut. Res., 2018, 25, 35657-35671.

54 F. G. Alabarse, R. V. Conceição, N. M. Balzaretti, F. Schenato and A. M. Xavier, Appl. Clay Sci., 2011, 51, 202-208.

55 X. Wang, S. Lu, L. Chen, J. Li, S. Dai and X. Wang, J. Radioanal. Nucl. Chem., 2015, 306, 497-505.

56 M. El Miz, H. Akichoh, D. Berraaouan, S. Salhi and A. Tahani, Am. J. Chem., 2017, 7, 105-112.

57 L. M. Calarge, A. Meunier and M. L. L. Formoso, J. South Am. Earth Sci., 2003, 16, 187-198.

58 H. A. Ahsaine, M. Zbair and R. El Haouti, Desalin. Water Treat., 2017, 85, 330-338.

59 J. Madejová, W. P. Gates and S. Petit, in Infrared and Raman Spectroscopies of Clay Minerals, ed. W. P. Gates, J. T. Kloprogge, J. Madejová and F. Bergaya, Elsevier, 2017, vol. 8, pp. 107-149.

60 C. T. Johnston, in Infrared and Raman Spectroscopies of Clay Minerals, ed. W. P. Gates, J. T. Kloprogge, J. Madejová and F. Bergaya, Elsevier, 2017, vol. 8, pp. 288-309.

61 M. L. Cantuaria, A. F. de Almeida Neto, E. S. Nascimento and M. G. A. Vieira, J. Cleaner Prod., 2016, 112, 1112-1121.

62 L. Bounab, K. Draoui, M. Ahrouch, M. Hadri, D. Bouchta and A. Barhoun, J. Mater. Environ. Sci., 2017, 8, 244-256.

63 A. Er-ramly and A. Ider, Phys. Chem. News, 2011, 61, 112-119. 64 H. N. Tran, C.-C. Lin, S. H. Woo and H.-P. Chao, Appl. Clay Sci., 2018, 154, 17-27.

65 I. Anastopoulos, I. Margiotoudis and I. Massas, Int. J. Phytorem., 2018, 20, 831-838.

66 M. Zbair, K. Ainassaari, A. Drif, S. Ojala, M. Bottlinger, M. Pirilä, R. L. Keiski, M. Bensitel and R. Brahmi, Environ. Sci. Pollut. Res., 2018, 25, 1869-1882.

67 D. Tang, Z. Zheng, K. Lin, J. Luan and J. Zhang, J. Hazard. Mater., 2007, 143, 49-56. 
68 T.-H. Pham, B.-K. Lee and J. Kim, Process Saf. Environ. Prot., 2016, 104, 314-322.

69 G. Xue, M. Gao, Z. Gu, Z. Luo and Z. Hu, Chem. Eng. J., 2013, 218, 223-231.

70 M. Momčilović, M. Purenović, A. Bojić, A. Zarubica and M. Ranđelović, Desalination, 2011, 276, 53-59.

71 A. Üçer, A. Uyanik and Ş. F. Aygün, Sep. Purif. Technol., 2006, 47, 113-118.

72 K. Kadirvelu, C. Faur-Brasquet and P. Le Cloirec, Langmuir, 2000, 16, 8404-8409.

73 C. Faur-Brasquet, Z. Reddad, K. Kadirvelu and P. Le Cloirec, Appl. Surf. Sci., 2002, 196, 356-365.

74 S.-T. Lin, H. N. Tran, H.-P. Chao and J.-F. Lee, Appl. Clay Sci., 2018, 162, 443-453.

75 A. Sharma, Z. Syed, U. Brighu, A. B. Gupta and C. Ram, J. Cleaner Prod., 2019, DOI: 10.1016/j.jclepro.2019.01.236.

76 F. Granados-Correa and J. Jiménez-Becerril, J. Hazard. Mater., 2009, 162, 1178-1184.

77 Y. Zeng, Z. Zeng, T. Ju and F. Zhang, Microporous Mesoporous Mater., 2015, 210, 60-68.

78 M. M. Rao, D. K. Ramana, K. Seshaiah, M. C. Wang and S. W. C. Chien, J. Hazard. Mater., 2009, 166, 1006-1013.
79 W. M. Ibrahim, A. F. Hassan and Y. A. Azab, Egypt. J. Basic Appl. Sci., 2016, 3, 241-249.

80 M. Kobya, E. Demirbas, E. Senturk and M. Ince, Bioresour. Technol., 2005, 96, 1518-1521.

81 R. R. Bansode, J. N. Losso, W. E. Marshall, R. M. Rao and R. J. Portier, Bioresour. Technol., 2003, 89, 115-119.

82 J. Yin, C. Deng, Z. Yu, X. Wang and G. Xu, Water, 2018, 10, 210.

83 Y. Ma, Q. Zhou, A. Li, C. Shuang, Q. Shi and M. Zhang, J. Hazard. Mater., 2014, 266, 84-93.

84 S.-H. Lin and R.-S. Juang, J. Environ. Manage., 2009, 90, 13361349.

85 H. N. Tran, S. J. You, A. Hosseini-Bandegharaei and H. P. Chao, Water Res., 2017, 120, 88-116.

86 H. N. Tran, S.-J. You and H.-P. Chao, J. Environ. Chem. Eng., 2016, 4, 2671-2682.

87 A. Elouahli, M. Zbair, Z. Anfar, H. A. Ahsaine, H. Khallok, R. Chourak and Z. Hatim, Surf. Interfaces, 2018, 13, 139-147.

88 H. Ait Ahsaine, Z. Anfar, M. Zbair, M. Ezahri and N. El Alem, J. Chem., 2018, 1-14.

89 M. Zbair, Z. Anfar, H. A. Ahsaine and H. Khallok, RSC Adv., 2019, 9, 1084-1094. 